\title{
EFL learners' cultural available lexicon: The effect of ELT textbooks
}

\author{
Andrés Canga Alonso ${ }^{1}$ \\ University of La Rioja \\ Daniela Cifone Ponte
}

University of La Rioja

\begin{abstract}
This research compares the cultural types elicited by twenty-nine EFL undergraduate students in response to two prompts from a lexical availability task (i.e. food and drink and countryside) and the cultural input provided by four last year High School ELT textbooks used in La Rioja. Cultural words were classified in terms of their frequency of appearance by means of Range and listed according to a framework of cultural topics (Risager, 1991; Byram, 1993; Byram \& Morgan, 1994; Common European Framework of Reference (CEFR, 2001). Finally, the words produced by the learners as well the input provided by the textbooks were associated with the culture they represented i.e. source, target and international culture. Our findings reveal that the number of words related to culture either elicited by students or included in the ELT textbooks is low. Most of the words students and textbooks provided belong to everyday living and international is the most representative culture in the study.
\end{abstract}

Keywords: Lexical availability, EFL, ELT textbooks, cultural types, source, target and international culture.

\section{RESUMEN}

Este estudio compara los tipos culturales producidos por veintinueve estudiantes universitarios de inglés como lengua extranjera en respuesta a dos centros de interés (alimentos y bebidas y el campo) de una prueba de disponibilidad léxica y el vocabulario cultural proporcionado por cuatro libros de texto de inglés utilizados en $2^{\circ}$ de Bachillerato en

1 Corresponding author - University of La Rioja, Department of Modern Philologies, San José de Calasanz, 33, 26004 Logroño (Spain).

Email: andres-canga@unirioja.es 
La Rioja. Las palabras obtenidas se clasificaron en función de su frecuencia por medio de la aplicación Range y se catalogaron de acuerdo con el modelo de temas culturales (Risager, 1991; Byram, 1993; Byram \& Morgan, 1994; Marco Común Europeo de Referencia (MCER, 2001). Por último, las palabras producidas por los alumnos, así como las proporcionadas por los libros fueron relacionadas con la cultura que representan es decir, cultura origen, meta e internacional. Nuestros resultados revelan que el número de palabras culturales, bien producidas por los estudiantes o incluidas en los libros de texto para la enseñanza del inglés es bajo. La mayoría de las palabras producidas por los participantes e incluidas en los materiales analizados pertenecen a la vida cotidiana, siendo la cultura internacional la que se encuentra más representada en el estudio.

Palabras clave: Léxico disponible, inglés como lengua extranjera, libros de texto de inglés como lengua extranjera, tipos culturales, cultura origen, meta e internacional.

\section{Introduction}

Teaching programmes in Spain aim at fostering students' intercultural competence. Consequently, vocabulary knowledge becomes a crucial aspect in foreign language learning (Nation, 2001), so that learners can express the cultural knowledge they have gained in the foreign language (FL). The ability to understand and negotiate both linguistic and cultural differences (Byram, 1997) should be also pivotal in formal instruction in order to be aware of the influence cultural aspects and behaviour may have in learning a foreign language. However, a frequent weakness of teaching programmes is that language and culture are often separated in the FL classroom and culture becomes little more than an addendum since ELT textbook editors do not pay close attention to cultural aspects in the materials they compile for secondary school education.

Lexical availability tasks have been widely used to test the number of words that emerge in response to a cue word in a language (López Morales, 1973; Jiménez Catalán \& Fitzpatrick, 2014). Nevertheless, research on lexical availability mainly explored Spanish as L1 or L2 and did not focus on EFL (Jiménez Catalán, 2014) and the influence ELT textbooks could have on students' cultural vocabulary. What is more, we have not found any evidence of studies with first year undergraduate Spanish EFL students which have focused on the analysis of the cultural vocabulary they elicit in response to the lexical availability cues and its relationship with the input provided by four ELT textbooks used in 2nd Baccalaureate. Hence, this paper tries to shed some light on the nexus among lexical availability, culture and the cultural component of ELT textbooks. A report of the study conducted with main results found and interpretation of the same follows. This paper concludes by pointing out some lines for further research trying to overcome the main limitations of the present study. 


\section{Lexical availability in foreign language teaching}

Lexical availability studies are based on a method to teach French to beginners called Le Français Élémentaire (1954). Initially, the aim was to teach French to the people who belonged to the union Française. Later, once these countries gained their independence, the original project was refocused on reinsuring that the citizens of the former French colonies continued to keep bonds with French language and culture. In the Élémentaire level great importance was given to vocabulary. Therefore, it became necessary to select the words that should be included in each level. Researching the frequent vocabulary consisted of compiling a representative corpus and converting it into electronic data. The result was a hierarchical list of words ranked on the base of frequency. That analysis soon proved to be an inappropriate methodology for identifying other lexical units that did not appear in their texts. In the early 1960's, Gougenheim, Michéa, Rivenc \& Sauvageot (1964) introduced the idea of working with association and started to distinguish between "frequent words" and "available words". Lexical availability tasks, then, were an artificial way of bringing to the surface the words available for immediate use by a given speaker, or a specific group of speakers. This new trend in lexical studies came to be understood as the vocabulary flow usable in a given communicative situation. The available lexicon of a given speech community started to be gathered through cue words known as centres of interest. Traditional lexical availability tasks include fifteen semantic fields or centres of interest related to daily situations (Animals, food and drink, clothes, parts of the body, jobs, means of transport, town, countryside, parts of the house, furniture, school, hobbies, the kitchen, gardening and light and central heating).

In 1973 López Morales begins in Puerto Rico the Pan-Hispanic Tradition. These works are not only limited to Puerto Rico, but quickly emerged in other countries, such as Mexico (López Chávez \& Strassburguer Frías, 1991), Dominican Republic (Alba Ovalle, 1995) and Chile (Echeverría \& Valencia, 1999). These studies mostly analysed the available lexicon of native speakers of Spanish in the aforementioned countries, but did not explore the influence culture might have in the words elicited by their informants. Lexical availability studies also arose in Spain with studies on Spanish L1 (Azurmendi, 1983; Benítez Pérez, 1992; Fuentes González, 1997; Garcia Marcos \& Mateo García, 1997; García Megía \& Garcia Marcos, 2005; Hernández Muñoz, 2010; Rodríguez Muñoz \& Muñoz Hernández, 2011; Samper Padilla \& Hernández Cabrera, 1997; Serrano Zapata, 2004). These pieces of research established comparisons among L1 speakers from the same region or from different regions, but they did not attempt to explore the cultural aspects that might be involved in participants' answers.

Lexical availability studies widened their scope to Spanish as a foreign language. In the same vein as in aforementioned studies with L1 speakers, scholars analysed the

Revista de Lenguas para Fines Específicos 22.2 
available lexicon of Spanish as a Foreign Language in Europe (González Fernández, 2013; Šifrar Kalan, 2014a and b) and China (Lin, 2012). However, to our knowledge, culture was not the scope of these studies. What is more, only two studies have considered the importance of culture and its influence on students' lexical availability (Carcedo, 1999; Benítez Rosende \& Wingeyer, 2012). Carcedo (1999) aimed at testing if 17-18 year-old Finnish and Spanish students' available lexicon contain words which were not part of their culture. These terms referred to concepts which have a different connotations in both countries (e.g. alcoholic drinks or feelings evoked by the countryside). Benítez Rosende \& Wingeyer (2012) explored the terms Argentinian students from the NEA region elicited in response to two prompts (Cultural myths and Countryside). They consider that this kind of research may provide effective tools in the development of materials for the teaching of culture in Spanish as a foreign language in the NEA region of Argentina. However, both studies approached cultural words from a perspective which differs from the scope of the present study whose aim is to compare the cultural input provided in $2^{\text {nd }}$ Baccalaureate ELT textbooks and the cultural words provided by a sample $1^{\text {st }}$ year undergraduate Spanish EFL learners.

In the twentieth first century, research on lexical availability started to focus its attention on EFL learners' available lexicon taking account of L1 (i.e. English or Spanish) (Ferreira \& Echeverría, 2014), sex (Jiménez Catalán \& Ojeda Alba, 2009), previous L2 knowledge (Gallardo del Puerto \& Martínez Adrián, 2014) and type of instruction (Germany \& Cartes, 2000; Jiménez Catalán \& Fitzpatrick, 2014; Fernández Orío \& Jiménez Catalán, 2015). However, to our knowledge, studies on first year undergraduate Spanish EFL learners' cultural word elicitation in response to two prompts from the lexical availability task (i.e. food and drink and countryside) have not been done.

Having analysed the origin, scope and relevance of lexical availability studies in Spanish L1, Spanish FL and EFL, the next section of this paper presents a review of the existing literature on the importance given to cultural vocabulary in ELT textbooks worldwide.

\section{Culture, cultural vocabulary and ELT textbooks}

As mentioned in the introduction, vocabulary knowledge is acknowledged to be of paramount importance to facilitate students' interaction in the foreign language. Previous studies have purported that those learners with a limited vocabulary repertoire find more difficulties when reading and writing texts in the L2 (Verhoeven, 1990; Jiménez, García \& Pearson, 1996; Hu and Nation, 2000). 
ELT textbooks have been considered one of the main resources for teachers and students (Richards, 2001; Ulrich, 2004). In fact, some studies ascertained that students' attitudes towards the foreign language they were taught were highly influenced by textbooks (Wright, 1999; Rahimi \& Hassani, 2012). In Spain, textbooks are the main tool a teacher has in language teaching; as a consequence, they are also the main vocabulary provider for students. For this reason, the selection of vocabulary and the activities which deal with it have become the main focus of scholars' attention Jiménez Catalán \& Mancebo Francisco, 2008; Criado, 2009; Criado \& Sánchez, 2012; Canga Alonso \& Cifone Ponte, 2015). Consequently, it seems necessary to explore the available vocabulary of a sample of Spanish EFL learners and its relationship with the input provided by the ELT materials they used in their last year of High School to shed some light on the relationship between input received and output produced by this sample of informants, as the present study sets out to investigate.

The process of learning a foreign language is a process of enculturation in which the learner acquires knowledge about the new culture/s and even gains awareness of their own culture (Alptekin, 2002). Concurrently, vocabulary is strongly linked to culture since words are different in each language not only in their form but in their meaning and are affected significantly by the feelings, ideas and experiences shared by the community in which they occur (Williams, 1976; Wierzbicka, 1997; Bennett, Grossberg \& Morris, 2005). In the same vein, the Common European Framework of Reference (CEFR, 2001) emphasizes that the cognitive organization of vocabulary and expressions is given by cultural features of those communities which the speaker has been in contact with. Moreover, the lexicon is a linguistic form where the influence of culture could be more noticeable and words can encode "culturally context conceptual systems" (Liddicoat \& Scarino, 2013, p. 28). As words carry a great load of meaning and connotations, their incorrect use or the lack of understanding or familiarity with the culture that surrounds them can lead to a misunderstanding in conversation and even provoke a breakdown in communication (Dimitrijevic, 1977; Baker, 2013).

The notion of culture in FL teaching also implies source, target and international culture (Risager, 1991; Kramsch, 1993; Byram, 1997). Source culture refers to students' native culture, whereas target culture is that culture or cultures involved in the study of a language. In more recent times, a third subtype has been added to this classification: international target culture (Cortazzi \& Jin, 1999; Alptekin, 2002; Tas, 2010). This later type of culture includes a great variety of cultures set in Englishspeaking countries or in other countries around the world. It exemplifies the manner in which English is used to communicate with others for international purposes. Lund (2006) emphasized the importance of finding an alternative to the Anglocentric orientation of Norwegian ELT textbooks to give students' the opportunity to 
experience and explore some other contexts in which English could be used as an international language. This latter classification of culture would provide students with basis to gain fuller understanding of how English as an international language (EIL) serves a great variety of international purposes in a broad range of contexts (e.g. economy, education, travel or broadcasting) (Crystal, 2000; McKay, 2003; Han \& Bae, 2005). The influence of context in EFL dates back to Kachru's (1985) three circles (inner, outer and expanding) through which English has spread over the centuries. The inner circle refers to the countries in which English is used as the first language. The outer circle involves those countries in which English is a powerful second language and the expanding circle refers to those countries in which English is a foreign language. Owing to the growing numbers of English speakers around the world in recent decades (Crystal 2000), Lund (2006) concluded that textbooks should include references to an international context-free culture, so that learners could gain knowledge of the world. This knowledge should help them reflect on their own culture and develop intercultural communication skills.

Despite culture has been considered something inherent to language and its lexicon, little research has been conducted about culture-related vocabulary in ELT textbooks. To our knowledge six studies have purported a content analysis of the culture-related vocabulary in English textbooks (Georgievska, 2000; Han \& Bae, 2005; Mahmood, Asghar \& Hussain, 2012; Xu, 2014, Silvia, 2014; Canga Alonso and Cifone Ponte, 2015). Georgievska (2000) conducted an analysis of two textbooks: the first a locallyproduced material used by secondary English students in Macedonia, whereas the second was internationally used. In order to compare both books, she offered a general description of the treatment of the cultural component on those textbooks and then, she considered them separately following Byram and Morgan's list (1994) and Risager's (1991) four category guide for the assessment of intercultural competence (IC). Her findings corroborated that both books had gaps regarding sociocultural vocabulary and when good opportunities of vocabulary related to culture were given, cultural connotations were not specified. In this vein, Han \& Bae (2005) created a list of criteria for the analysis of cultural content in English textbooks in Korea based on the literature on evaluation of the cultural content in textbooks. They came to the conclusion that there was not much difference in cultural content between materials written by native speaker writers and those written by Korean ELT writers.

As for the presence of references to source, target and international culture in ELT textbooks, Mahmood, Asghar and Hussain (2012) carried out a quantitative content analysis of an ELT textbook in Pakistan to establish which culture was predominant in it and if there were references to learners' native culture. The lack of information about the students' native culture was their main concern and they claimed that 
textbooks should represent just the target culture and avoid representing international cultures. On the contrary, Canga Alonso and Cifone Ponte (2015) explored the cultural vocabulary of two ELT textbooks from two different levels of Spanish education ( $4^{\text {th }}$ grade of secondary education and $2^{\text {nd }}$ baccalaureate). Their findings revealed that these two ELT materials tended to focus on the target culture. They also ascertained that the total number of words related to culture encountered was not balanced. Geographical locations and famous or influent characters were highlighted, whereas controversial topics (e.g. politics and religion) were not present in their corpus.

Nevertheless, this predominance of the target or international cultures over the source one is not a global trend in ELT materials. Thus, Xu (2013) explored five volumes of a locally produced textbook in China. He focused on all the texts in the five volumes to test how they enabled Chinese EFL learners to associate their own daily life activities and cultures. His findings showed that the ongoing globalization and multicultural awareness, alongside the paradigm shift to teaching EIL in the Chinese context have engendered desirability for incorporating multicultural and multimodal ELT materials in China. These textbooks also focused on the source culture since "It is (...) natural and timely to focus on the local learners as the legitimate users of English in the ELT materials (2014, p. 19).

Finally, Silvia (2014) aimed at analysing the cultural content of English textbooks used in Jakarta and its implication in facilitating intercultural communicative competence. The study found that the in-use English textbooks portrayed cultures mainly in the form of visuals. They were represented mostly by their products and persons.

Considering the aforementioned studies on cultural vocabulary and ELT textbooks in Spain and worldwide, it can be stated that former research has not found concluding evidence to support the supremacy of target or international culture over the source one. This inconclusive evidence is also applicable to the cultural vocabulary elicited by EFL learners in Spain in response to lexical availability tasks and its relationship with the input provided by ELT textbooks used in Spanish secondary school. Henceforth, the present study aims to shed some light on the connections between ELT textbooks' input and students' available lexicon in terms of cultural words, to classify the terms elicited by our informants according to source, target or international culture and to classify them according to the framework of cultural topics (Byram, 1993; Byram \& Morgan, 1994; CEFR, 2001; Risager, 1991; Sercu, 2000; Canga Alonso and Cifone Ponte, 2015), which will be presented in section 5.2.

\section{Research questions}


The present study sets out to find answers to the following research questions

- RQ1: Are the most frequent types elicited by the participants also the most frequent ones in the ELT textbooks analysed in the present research?

- RQ2: Do the cultural topics represented in students' responses to the lexical availability task correspond with the input provided by ELT textbooks?

- RQ3: Is the culture (i.e. source, target or international) represented in the vocabulary of ELT textbooks part of the students' available lexicon?

\section{Methodology}

\subsection{Participants}

The sample was made up of $291^{\text {st }}$ year undergraduate EFL learners from two degrees in the area of Humanities (i.e. History and Geography and Spanish Language and Literature) from a university in the North of Spain. The students ages ranged from 1731 (Mean: 18.8). As far as the sex of the participants, there were 13 females and 16 males. $65.5 \%$ of the participants received private lessons in English. Table 1 illustrates the diversity in the number of students and the period of time they have spent learning English outside the school on a two-week-hour basis.

\begin{tabular}{lllllllll}
\hline $\mathbf{6}$ months & $\mathbf{1}$ year & $\mathbf{2}$ years & $\mathbf{3}$ years & $\mathbf{4}$ years & $\mathbf{6}$ years & $\mathbf{1 0}$ years & $\mathbf{1 2}$ years & $\mathbf{1 4}$ years \\
\hline 1 & 3 & 3 & 2 & 2 & 4 & 1 & 1 & 2 \\
\hline
\end{tabular}

Table 1. Formal EFL instruction outside school.

Finally, 27.6\% spent a short period of time in an English speaking country, mostly in the UK and the USA.

\subsection{Procedures}

Data was collected one day during class time. Students' were asked to respond to fifteen prompts from the lexical availability task. The time was controlled by the researcher and the participants were given two minutes to provide as many words as possible from each of the cue words from the lexical availability task. Clear instructions were given both orally and in written form in students' L1 to clarify what they were being asked to do. Informants also answered a background questionnaire and signed consent forms.

This paper will focus on students' responses to two prompts: 'Food and drink' and 'Countryside'. 'Food and drink' was chosen since it is one of the most productive prompts in Spanish as L1 (García Casero, 2013; Cepeda Guerra, Granada Azcárraga \& 
Pomes Correa, 2014), Spanish as a foreign language (Gallego Gallego, 2014; Jin, 2012; López González, 2014; Šifrar Kalan, 2014a; Šifrar Kalan, 2014b) and EFL (Gallardo del Puerto \& Martínez Adrián, 2014; Jiménez Catalán \& Fitzpatrick, 2014) and we wanted to test if it would be the most productive in cultural terms. As for 'Countryside', it is one of the least productive centres of interest in former lexical availability literature (Magnúsdóttir, 2012; González Fernández, 2013; Šifrar Kalan, 2014a). However, it is closely related to culture (Benítez Rosende \& Wingeyer, 2012), so we wondered if students' elicited cultural words about this semantic field. What is more, Spanish EFL learners are more exposed to 'Food and Drink' than to the 'Countryside' Jiménez Catalán \& Ojeda Alba, 2009), so our main concern is to confirm if previous knowledge was reflected in students' responses to each of the prompts.

Answers were edited and included in an excel spreadsheet. Based on previous studies (Jiménez Catalán \& Ojeda Alba, 2009; Samper Hernández \& Jiménez Catalán, 2014), brand names (e.g. Coca Cola, Lucozade) were deleted. Spelling mistakes were corrected. Words in plural were changed into singular. Repeated words in the same prompt were deleted and verbs were changed to bare infinitive.

Reading comprehension activities as well as listening tapescripts from four textbooks Top Marks 2, Move On 2, Advanced Contrast 2 and Viewpoints 2 were examined. Our sample of textbooks represents geographical variation since they were used in nine public High Schools from different towns and villages in La Rioja. All the textbooks are especially designed for Spanish $2^{\text {nd }}$ Baccalaureate curriculum and are not sold anywhere else in the world, except for Spain. Thus, their intended audience is $2^{\text {nd }}$ Baccalaureate EFL learners in Spain. They were two-level courses, therefore the books analysed correspond with level 2. As stated in the introduction to the Teacher's Book of each of the materials analysed in this study, Top Marks 2 (Woods and Grant, 2007) provides students with a wide selection of topics and enriches the student's knowledge of cultural aspects of the English-speaking world through cultural references in the reading texts (Rubio Santana and Grant, 2007). Move On 2 (Krantz, 2012) contains lively reading texts on a range of social, cultural and scientific themes to motivate, challenge and engage students (Dignen, 2012). Advanced Contrast 2 provides students with a wide selection of varied topics relating English with other areas of the curriculum and introducing cultural aspects of the English-speaking world (Rubio Santana 2013). Viewpoints 2 (Grant \& Payne, 2010) offers a challenging programme which not only prepares students for the university entrance examinations but also enables them to use English in real-life situations. Topics introduce cultural aspects of the English-speaking world (Rubio Santana \& Grant, 2010).

As abovementioned, listening and reading activities from students' and teacher's books/guides were scrutinised. We focused on these two areas since they refer to 
written and oral skills, which are basic for communication. What is more, previous studies have purported the influence of reading comprehension (Tomlinson, 2002; Basabé, 2003; Ghaniabadi \& Alavi, 2012; Gómez, 2012) or listening activities (Hayati, 2009) in regard with culture but they have not studied the relationship between the cultural input provided by ELT textbooks and the cultural vocabulary stored in the learner's mind in response to a lexical availability task.

A cultural-related framework (Byram, 1993; Byram \& Morgan, 1994; Sercu, 2000; CEFR, 2001; Hall 2002) was compiled to conduct the analysis of the vocabulary present in the textbooks to compare it with the words elicited by the informants in response to the lexical availability task. This classification is relevant for this study as it will allow stating which cultural topics are the most recurrent and which of those are left aside by textbook publishers. As illustrated in table 2 the list includes twelve categories which represent different aspects of culture:

\begin{tabular}{ll}
\hline Cultural Topic & Semantic fields \\
\hline Everyday living & Food, drink, leisure activities, clothes, housing. \\
\hline Cultural heritage & $\begin{array}{l}\text { Famous monuments and people, literature, TV } \\
\text { shows, movies, music. }\end{array}$ \\
\hline National identity & $\begin{array}{l}\text { Languages, religions, nationality, history, humour, art } \\
\text { and politics. }\end{array}$ \\
\hline Popular culture & $\begin{array}{l}\text { Rites, traditions, celebrations, festivals, social } \\
\text { conventions, dances, discos, religious observances } \\
\text { and values, types of music. }\end{array}$ \\
\hline Society & $\begin{array}{l}\text { Living standards, classes, urban tribes, minorities, } \\
\text { family structures, regional cultures and subcultures. }\end{array}$ \\
\hline Geography & $\begin{array}{l}\text { Countries, continents, cities, towns, streets, } \\
\text { countryside. }\end{array}$ \\
\hline Stereotypes & Typical features attributed to certain cultures. \\
\hline Language & Borrowings, informal register, idioms, collocations. \\
\hline Worldwide issues & Political, economic, social and environmental issues. \\
\hline Institutions and & $\begin{array}{l}\text { Official institutions and organizations from different } \\
\text { countries. }\end{array}$ \\
\hline organizations & Words from other varieties of English. \\
\hline Socialies & Greetings, apologies, politeness \\
\hline
\end{tabular}

Table 2.

Framework of cultural content in ELT textbooks (Adapted from: Byram, 1993; Byram \& Morgan, 1994; CEFR, 2001; Risager, 1991; Sercu, 2000; Canga Alonso and Cifone Ponte, 2015).

For the purpose of the present research and taking account of the two prompts selected from the lexical availability task (i.e. food and drink and countryside) the list was reduced to four topics with their corresponding semantic fields: everyday living, 
popular culture, language and geography. Everyday living, was selected directly from the CEFR (2001). Geography was extracted from Byram (1993), Byram \& Morgan's (1994), Sercu (2000) and Risager's (1991) macro-level- social, political and historical matters. Popular Culture corresponds with Byram's (1993) belief and behaviour theme. As there was no specific area of study regarding language in the framework, it was considered necessary to add this topic to the list since Gray (2010) considers that spoken language is key in culture. Furthermore, people communicate through language and languages borrow words from one another: As mentioned in section 3, the influence of EIL (Kachru, 1985; Crystal, 2000) makes necessary for contact languages from the expanding circle to borrow words from different contexts (e.g. economy, education, travel or broadcasting) and this paper aims to explore if these words are included in the sample of textbooks analysed in the present study.

Data analysis was performed by classifying and obtaining quantities and percentages using Microsoft Excel ${ }^{\oplus}$ both for students' responses to the task and cultural words that were found in textbooks. As for textbooks, each classification was done separately in order to obtain different quantities and percentages from each book so we could proceed to compare them. Besides, the Range Program with ASL/AWL list (http://www.victoria.ac.nz/lals/about/staff/paul-nation) was used to identify the number of tokens, types and word frequencies included both in textbooks and students' answers. Type is a class of linguistic item, whereas token refers to an example of occurrence of a type (Nation 2001).

\section{Results}

Two main factors were taken into account to answer RQ1 (Are the most frequent types elicited by the participants also the most frequent ones in the ELT textbooks analysed in the present research?): (i) the number of cultural tokens and types elicited by the participants and the number of cultural tokens and types provided by the four ELT textbooks to verify which prompt was the most/least productive in terms of students' responses and textbook input and (ii) the degree of coincidence between input provided and students' responses by means of the frequency of appearance of each word which was elicited by our informants.

As for the number of cultural tokens and types prompted by the participants, table 3 shows that the number of tokens was slightly higher in favour of 'Food and drink', although the number of types was exactly the same for both centres of interest. These results concur with previous studies with younger EFL learners in Spain Jiménez Catalán \& Fitzpatrick, 2014) and Spanish as a foreign language in Slovenia (Šifrar Kalan, 2014b). In both studies, 'Food and drink' was the most productive prompt in terms of

Revista de Lenguas para Fines Específicos 22.2 
tokens and types, but the difference between them diminished considerably with regard to the number of types as occurs in the present study.

\begin{tabular}{lll}
\cline { 2 - 3 } & Tokens & Types \\
\hline Food and drink & 93 & 24 \\
\hline Countryside & 87 & 24 \\
\hline
\end{tabular}

Table 3. Lexical availability cultural output distributed by prompt.

The four ELT textbooks purported similar results to the ones obtained in the lexical availability task. However, some deviations were stated since the input provided varies according to each teaching material. Thus, Top Marks presented the highest number of cultural types as far as 'Food and drink' is concerned closely followed by Viewpoints. Table 4 also shows that Top Marks nearly doubled the number of types included in Advanced Contrast. As for 'Countryside', Move on offered the highest number of types for the semantic field of 'Countryside', closely followed by Top Marks and Viewpoints. As happened with 'Food and drink', Advanced Contrast displayed the lowest number of cultural types.

\begin{tabular}{lllll} 
& \multicolumn{2}{l}{ Food and drink } & Countryside \\
\cline { 2 - 5 } & Tokens & Types & Tokens & Types \\
\hline Top Marks & 20 & 13 & 15 & 11 \\
\hline Move On & 12 & 9 & 14 & 12 \\
\hline Advanced Contrast & 16 & 7 & 9 & 8 \\
\hline Viewpoints & 19 & 11 & 20 & 11 \\
\hline
\end{tabular}

Table 4. Cultural input distributed by prompt.

Tokens are also relevant for our analysis since they indicate the number of times a given word occurs in each of the four textbooks object of the present study. Advanced Contrast was once again the material with the lowest rank of tokens for the field of 'Countryside', whereas Move On was the one with the lowest number of tokens on 'Food and drink'.

In regard with the degree of coincidence between the input provided and students' responses by means of the frequency of appearance, our findings evince that there is a divergence between both prompts. As illustrated in figure 1, twelve types produced by the participants in response to 'Food and drink' corresponded with the input provided in ELT textbooks. This figure also reveals that the relationship between input and output does not apply for the four books since only two types (hamburger and coffee) appeared in three of them (Top Marks, Advanced Contrast and Viewpoints) whereas five types (wine, coke, pasta, tea and junk food) were repeated in two textbooks. On the contrary, pizza, chips, bacon, cookie and grape were only present in one of the materials. 


\section{Food and drink}

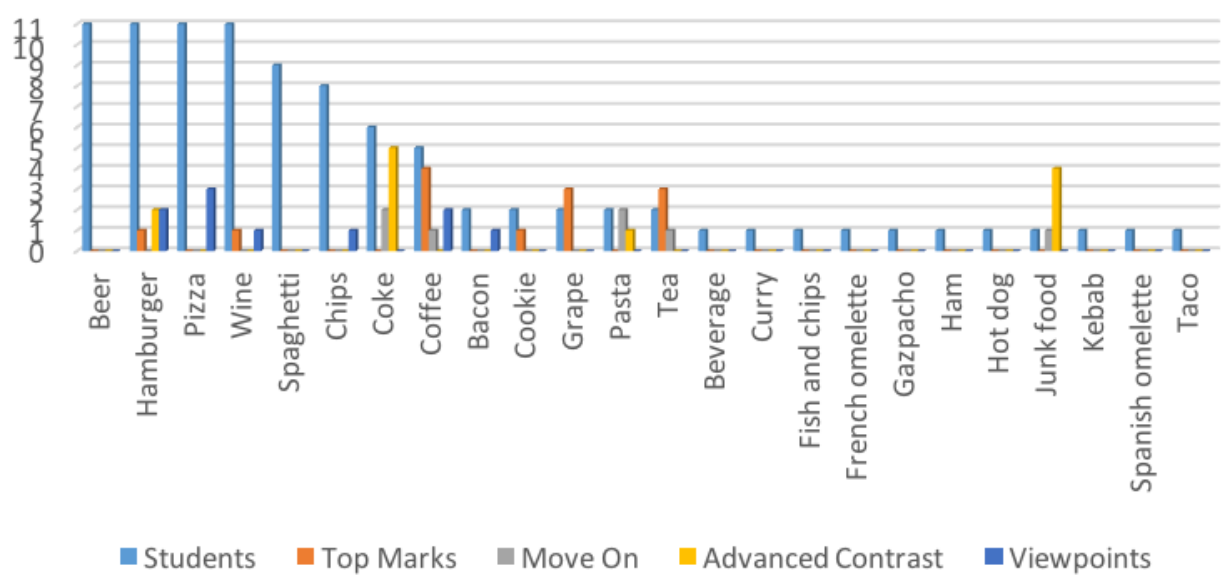

Figure 1. Degree of coincidence between input and output: Food and drink.

As for 'Countryside', the number of types which concurred with the input provided by the books evaluated in our research was a bit lower since eleven types were present in the four books tested. However, the degree of deviation between input and output was higher in this prompt since only three types (wild, farm and farmer) appeared in two textbooks whereas the rest of the types were only present in one book. Figure 2 illustrates these findings.

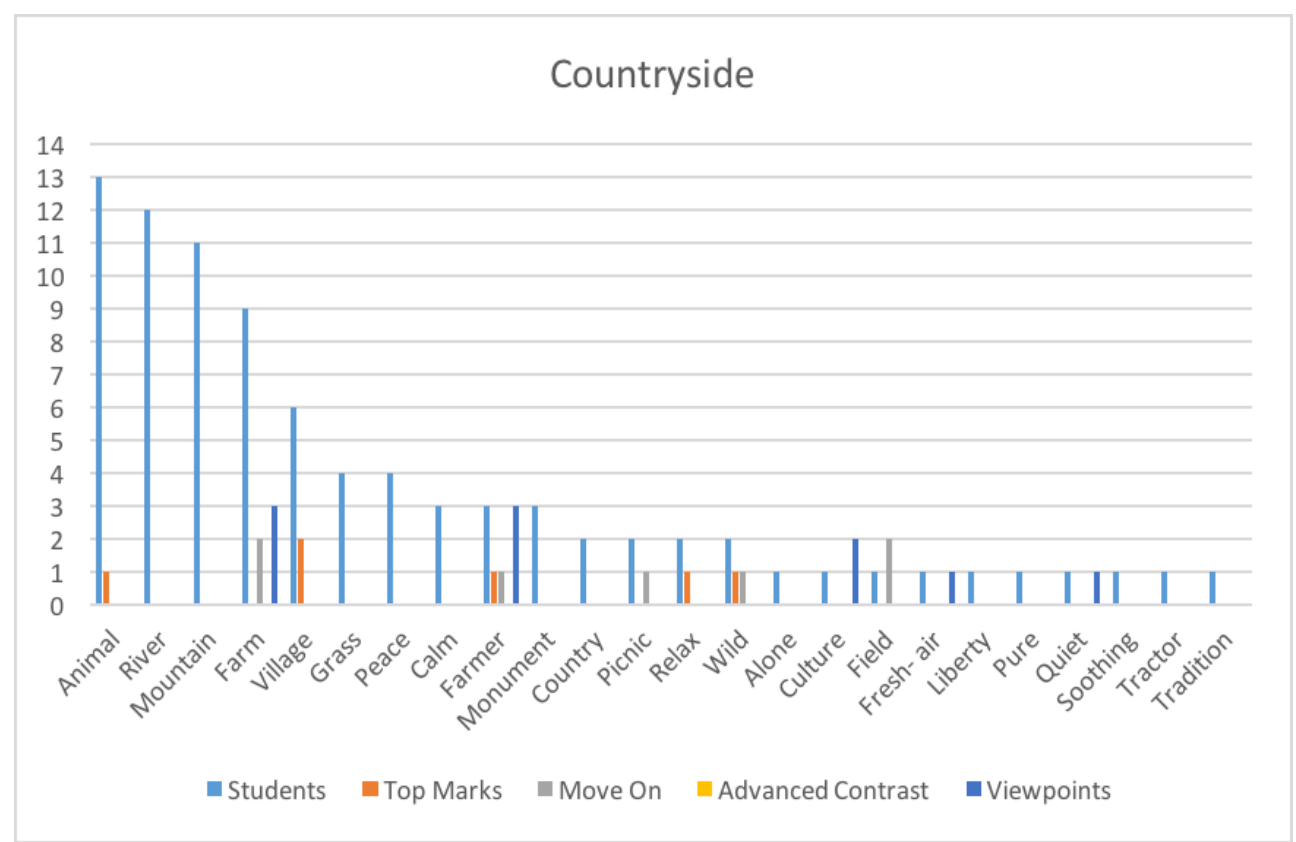

Figure 2. Frequency of tokens in students' responses and ELT textbooks: Countryside 
As far RQ2 (Do the cultural topics represented in students' responses to the lexical availability task correspond with the input provided in ELT textbooks?) is concerned, students' answers evince that food was the most productive cultural topic in the sample. This topic was the most productive in textbooks too. Geography-countryside was quite productive in our informants, but less frequent in the ELT materials. Finally, popular culture and language borrowings were quite scarce both in learners' responses to the lexical availability task and the input provided by the ELT books surveyed in the present study.

RQ3 (Is the culture (i.e. source, target or international) represented in the vocabulary of ELT textbooks part of the students' available lexicon?) reveals that international culture was the most frequent type of culture found in students' responses and ELT materials, whereas the source culture showed the lowest findings. Table 5 shows these facts.

\begin{tabular}{llll}
\hline Cultural Topics & Source Culture & Target Culture & International Culture \\
\hline Everyday living-Food & Wine, grape, coffee & $\begin{array}{l}\text { Tea, chips, } \\
\text { bacon }\end{array}$ & $\begin{array}{l}\text { Hamburger, coke, } \\
\text { cookie, junk food }\end{array}$ \\
\hline Popular culture & picnic & culture \\
\hline $\begin{array}{l}\text { Geography- } \\
\text { countryside }\end{array}$ & & $\begin{array}{l}\text { Wild, farm, farmer, } \\
\text { village, quiet, fresh-air }\end{array}$ \\
\hline Language- & & Pasta, pizza, relax \\
Borrowings & & \\
\hline
\end{tabular}

Table 5. Cultural topics and represented cultures.

\section{DISCUSSION}

Research question one posed whether the most frequent words elicited by students are also the most frequent in the ELT textbooks. Our findings reveal that there is a $50 \%$ correspondence between the cultural types elicited by students' in response to 'Food and Drink' and the cultural input provided by ELT textbooks. This percentage is slightly lower (45.83\%) for 'Countryside'. The number of tokens is higher for 'Food and Drink' both in textbooks and participants' answers to the task. This result concurs with Jiménez Catalán \& Ojeda Alba (2009) since students' are more exposed to 'Food and Drink' than to 'Countryside', which makes them produce more words about this semantic field. In the same vein, traditional studies on lexical availability with younger EFL Spanish students (Jiménez Catalán \& Fitzpatrick, 2014; Fernández Orío \& Jiménez Catalán, 2015) and adult learners (Gallardo del Puerto \& Martínez Adrián, 2014) conclude that 'Food and Drink' is the most productive prompt. This tendency is shared with the Pan-Hispanic tradition either in Spanish L1 (García Casero, 2013; Cepeda Guerra, Granada Azcárraga \& Pomes Correa, 2014) and Spanish as a foreign language 
(Gallego Gallego, 2014; Jin, 2012; López González, 2014; Šifrar Kalan, 2014a; Šifrar Kalan, 2014b). Following these findings, our results could be interpreted in terms of learners' greater exposure to 'Food and Drink'. The second reason to explain this finding relates to the fact that words such as hamburger or pizza, are not only present in textbooks but also in daily situations since most of the words our informants elicited about food and drink (i.e. hamburger, pizza, pasta, cookie, coke, bacon coffee) are associated with teenagers' food habits. It is noteworthy the presence of borrowings from Italian (pasta, pizza) which have been included into Spanish and English. We also encountered instances of English words (bacon and picnic) which have been included into Spanish. Both findings concur with previous studies on lexical availability in Spanish L1 in Andalusia (Rodríguez Muñoz \& Muñoz Hernández, 2011).

Similarly, Rodríguez Muñoz \& Muñoz Hernández (2011), 'Countryside' does not include proper terminology related to the country, but it does include types which refer to sensation and feelings (relax, wild, quiet, fresh-air). This fact seems to imply that our sample of learners' as well as the textbooks object of the present study associate the countryside with feelings quietness and tranquillity as opposed to towns where everything moves faster. What is more, most teenagers in La Rioja tend to spend some time in the village (countryside) with relatives during school holidays. Hence, they might associate the countryside with this feeling of peacefulness. This outcome may show the culture of students themselves as being central to ELT, 'whether as the basis of the culture of the classroom (...) or simply because of its potential to stimulate language practice' Gray (2010, p. 173). This result also echoes Lund's assertions that textbooks should include references to different cultural contexts, so that learners have an "opportunity to experience and explore some of the contexts in which English can be used as a lingua franca and also to free themselves from native speakers norms" (2006, p. 74). Concurrently, it would be interesting to compare the words English L1 speakers produce in response to this cue word to explore whether cultural differences or similarities could be shown between both groups of undergraduate students.

We now move to the discussion of the results of our second research question to explore whether the cultural topics represented in students' responses to the lexical availability task resembled the cultural topics present in the ELT textbooks. Our figures confirm the connection between students' responses and the vocabulary they have been exposed to. Thus, Everyday living-food is the most productive cultural topic in our sample, which concurs with the high lexical frequency of food in previous lexical availability studies with Spanish EFL leaners (Gallardo del Puerto \& Martínez Adrián, 2014; Jiménez Catalán \& Fitzpatrick, 2014; Fernández Orío \& Jiménez Catalán, 2015). This result differs from previous studies on cultural vocabulary in textbooks in Spain (Canga Alonso and Cifoen Ponte, 2015) and abroad (Alkatheery, 2011; Han \& Bae, 
2005; Mahmood, \& Ashgar and Hussein, 2012; Silvia, 2014). Popular culture was the most representative cultural topic in Canga Alonso and Cifone Ponte (2015), Han \& Bae (2005) and Silvia (2014) whereas social identity (socialization) was the most frequent in Alkatheery (2011) and Mahmood, Ashgar \& Hussein (2012). The scope of the books and the intended audience could be the reason to account for this divergence with previous studies either in the same country or abroad. As mentioned in section 5.2., the four textbooks tested in the present paper are only published in Spain for $2^{\text {nd }}$ Baccalaureate students. In addition, Top Marks, Advanced Contrast and Viewpoints belong to the same publishing house which only works in Spain. On the contrary, one of the books analysed in Canga Alonso and Cifone Ponte's (2015) is intended for B1 international students at secondary level. Alkatheery (2011) scrutinised books to prepare students for TOEFL and Mahmood, Ashgar \& Hussein (2012) focused on university teaching materials. It, then, seems that there is a tendency to focus on everyday living at this level of High School in Spain, which concurs with our previous assertion that the culture of the students is key to ELT. These data also concur with Georgievska's (2000) claim that ELT books have gaps regarding socio-cultural vocabulary and that is why the present sample of materials only refers to everyday living giving less prominence to other topics such as popular culture or language. This lack of input about language is also accordance with Silvia's (2014) textbook content analysis in Jakarta, since cultures are mostly represented by products or persons. Nevertheless, the scarcity of references to popular culture and language in our research may not imply that these two topics are not present in our corpus of ELT textbooks since it is sometimes difficult to encapsulate culture in isolated words. Further research is called to explore learners' reactions to a task based on images which refer to cultural representations (e.g. festivals or events) to explore if they are able to elicit cultural words as Gray (2010) claims.

As for our third research question (Is the culture (i.e. source, target or international) represented in the vocabulary of ELT textbooks part of the students' available lexicon?), our data evince that source, target and international culture are not presented in a balanced proportion in the present research. International culture is the most frequent type culture in our sample. This outcome concurs with previous studies with international (Han \& Bae, 2005; Alkatheery, 2011; Shin, Eslami \& Chen, 2011, Canga Alonso and Cifone Ponte, 2015) and localised textbooks (Tajeddina \& Teimournezhadb, 2015). On the contrary, cultural types about target culture are scarce in our research which differs from previous studies where it is the most recurrent (Han and Bae, 2005; Alkatheery, 2011; Shin, Eslami \& Chen, 2011; Canga Alonso and Cifone Ponte, 2015; Tajeddina \& Teimournezhadb, 2015). The emergence of international culture over source and target ones could be interpreted in terms of globalization since the rise of EIL in western expanding circle countries implies that exposing learners to a single culture is no longer considered sufficient as intercultural

Revista de Lenguas para Fines Específicos 22.2 
language teaching and understanding gains momentum (Lund 2006). The current situation in Spain may also account for the higher number of words related to international culture. It is a western country influenced by the politics of the EU, so traditions and values are mostly shared with other state-members. What is more, one of the aims of the EU is to build bridges between its different member states and to eliminate barriers among them. Thus, international culture prevails over source or target ones.

Finally, the scarcity of references to the source culture could be explained on the scope of the materials analysed in the present study whose main aim is to enrich the students' knowledge of cultural aspects not only applied to English-speaking countries, but to any context in which English is used as an international language. This outcome concurs with the recommendations included in the Curriculum in La Rioja since students should develop attitudes of respect to other people, languages cultures using English as the vehicular language (Decreto 21/2015, 26 ${ }^{\text {th }}$ June). As abovementioned, this outcome contrasts with several studies conducted in eastern expanding circle countries (Sudartini, 2012; Chinh 2013; Xu 2013) which assert that it is natural and timely to focus on the local learners as the legitimate users of English in the ELT materials to promote national culture so that the target culture will not be considered superior to the native one. Thus, the importance each teaching resource gives to source, target or international cultures seems to be influenced by national or regional curriculum constrains.

\section{Conclusion}

Three main findings stem from the present research study. First, the number of cultural words elicited by our informants in response to 'Food and Drink' and 'Countryside' is scarce which corresponds with the low number of cultural types present in the four ELT textbooks examined in this paper. The aforementioned terms mostly relate to the cultural topic everyday living-food which is also the most frequent in the materials analysed. This constitutes our second outcome. Finally, international culture is the most representative in our sample, which concurs with the idea of globalisation and the rise of English as a lingua franca, spoken worldwide by speakers from different backgrounds.

Our results lead us to think that the number of cultural types included in the sample of ELT textbooks analysed in the present study is limited. This scarcity of input leads to students' reduced number of cultural types in response to the cue words 'Food and Drink' and 'Countryside'. It seems that culture is not be part of ELT materials in $2^{\text {nd }}$ Baccalaureate. Nevertheless, these findings should be taken with caution due to the size of the sample and the nature of our analysis which is based on cultural related

Revista de Lenguas para Fines Específicos 22.2 
vocabulary which is sometimes difficult to be related to a given culture. Further studies are necessary, which explore the cultural input of a wider sample of informants and ELT textbooks. If the scope of our study were widened with more informants and textbooks the results might be different. Besides, vocabulary knowledge also relates with language proficiency, therefore further studies are called to analyse the cultural words elicited by EFL learners according to their English level and the input provided by ELT textbooks. Attitudes to culture might also influence on students' cultural vocabulary knowledge to correlate cultural types elicited with positive/negative attitudes towards the English language and culture. Finally, the traditional cue words from the lexical availability task might also be changed to include other prompts (i.e. travel, or education) which are closer to cultural attitudes and values. Further research is called for to overcome these limitations.

\section{About the authors}

Andrés Canga Alonso is a full-time lecturer of English Studies at the University of La Rioja (Spain). His main research focuses on the applications of e-mail tandem and autonomy in mixed-ability EFL learners, the analysis of receptive and productive vocabulary of primary and secondary CLIL and non-CLIL learners, EFL leaners' cultural available lexicon at the end of Baccalaureate and the use of language portfolios in EFL and translation. He has participated in several projects on receptive vocabulary and EFL leaners' available lexicon. He has published different papers on the abovementioned fields in International Journal of Applied Linguistics, International Journal of English Studies, and Revista Española de Lingüística Aplicada (RESLA).

Daniela Cifone Ponte is a PhD student at the Department of Modern Philologies (University of La Rioja). She is currently working on her PhD thesis which focuses on the cultural vocabulary of $2^{\text {nd }}$ Baccalaureate ELT textbooks in La Rioja.

\section{Acknowledgements}

The authors would like to acknowledge the financial support of the Spanish Ministry of Economy and Competitiveness through grant $n^{\circ}$ FFI 2013-47707-P. 


\section{LFE Article history}

Paper received: 01st December 2016

Paper received in revised form and accepted for publication: 26th June 2016

\section{References}

Alba Ovalle, O. (1995). Léxico disponible de la República Dominicana. Santiago de los Caballeros: Pontificia Universidad Católica Madre y Maestra.

Alkatheery, E. R. (2011) Content analysis of culture in ELT reading textbooks: Appropriacy and inclusivity. MA Thesis. Department of English at the College of Arts, King Saud University.

Alptekin. C. (2002). Towards intercultural communicative competence in ELT. ELT Journal, 56 (1), 57-64.

Azurmendi, M. J. (1983). Elaboración de un modelo para la descripción sociolingüística del bilingüismo y su aplicación parcial a la Comarca de San Sebastián. Guipúzcoa: Caja de Ahorros Provincial de Guipúzcoa.

Baker, W. (2013). From cultural awareness to intercultural awareness: Culture in ELT. ELT Journal, 56 (1), 62-70.

Basabe, E. A. (2004). Cultures in ELT textbooks. A critical comparative analysis of the representations of the source culture, the local culture and the international culture in global, adapted and local materials. MA Thesis. Warwick: Centre for English Language Teacher Education, University of Warwick.

Benítez Pérez, P. (1992). Disponibilidad léxica en la zona metropolitana de Madrid. Boletín de la Academia Puertorriqueña de la Lengua Española, 1(1), 71-102.

Benítez Rosende, C. A., \& Wingeyer, H. R. (2012). Los mitos en la disponibilidad léxica del NEA de Argentina. Aportes para la enseñanza de la cultura a extranjeros. I Congreso de la Delegación Argentina de la Asociación de Lingüística y Filología de América Latina (ALFAL) y V Jornadas Internacionales de Filología Hispánica La Plata, FaHCE-UNLP (pp.1-10). $<$ http://jornadasfilologiaylinguistica.fahce.unlp.edu.ar> [10/10/2015].

Bennett, T., Grossberg, L. \& Morris, M. (2005). New keywords: A revised vocabulary of culture. Malden: Blackwell Pub.

Byram, M. (Ed.) (1993). Germany/Its representation in textbooks for teaching German in Great Britain. Frankfurt: Verlag Moritz Diesterweg.

Byram, M. 1997. Teaching and assessing intercultural communicative competence. Clevedon: Multilingual Matters.

Revista de Lenguas para Fines Especificos 22.2

ISSN: $2340-8561$ 
Byram, M., \& Morgan, C. (1994). Teaching-and-learning language-and-culture. Clevedon: Multilingual Matters.

Canga Alonso, A., \& Cifone Ponte, D. (2015). An analysis of cultural vocabulary in ELT textbooks. Odisea, 16, 83-96.

Carcedo, A. (1999). Índices léxico-estadísticos y graduación del vocabulario en la enseñanza de ELE (Aspectos Culturales). ASELE: Actas X, 175-184.

Cepeda Guerra, M., Granada Azcárraga, M., \& Pomes Correa, M. (2014). Disponibilidad léxica en estudiantes de primero básico. Literatura y Lingüística, 30, 181-206.

Chinh, N. D. (2013). Cultural diversity in English language teaching: learners' Voices. English Language Teaching, 6(4), 1-7. <http://www.ccsenet.org/journal/index.php/elt/article/ view/25557/15808>. [13/06/2016].

Common European Framework of Reference for Language. Learning, Teaching and Assessment. (2001). Cambridge: Cambridge University Press.

Cortazzi, M. \& Jin, L. (1999). Cultural mirrors: Materials and methods in EFL classroom. In Hinkel, E. (Ed.), Culture in second language teaching (pp. 196-219). Cambridge: Cambridge University Press.

Criado, R. (2009). The distribution of the lexical component in ELT coursebooks and its suitability for vocabulary acquisition from a cognitive perspective. A case study. $\begin{array}{lllll}\text { International Journal of English Studies, } 9 & \text { (3), 39-60. }\end{array}$ $<$ http://revistas.um.es/ijes/article/view/99511/95091>. [20/10/2015].

Criado, R., \& Sánchez, A. (2012). Lexical frequency, textbooks and learning from a cognitive perspective. A corpus-based sample analysis of ELT materials. RESLA Extra, 1, 77-94.

Crystal, D. (2000). English as a global language. Cambridge: Cambridge University Press.

Decreto 21/2015, de 26 de junio, por el que se establece el currículo de Bachillerato y se regulan determinados aspectos sobre su organización, evaluación, promoción y titulación del alumnado de la Comunidad Autónoma de La Rioja. $<$ https://ias1.larioja.org//cex/sistemas/GenericoServlet?servlet=cex.sistemas.dyn.portal.ImgServletSis\& code=oumCvWIgBUF61Chv9ZDgP\%2FhXhSM\%2FFmcHPQpqchJy7ovApHyqPVxRsoD\%2BHW0E 2YV6LEXZYSr1AOEv\%0As5MOTQg0Pduj3yrM3TP5f\%2F5wfx5pENs\%3D\&\&\&>. [26/05/2016].

Dignen, S. (2012). Move On 2 (Teacher's Guide). Oxford: Oxford University Press.

Dimitrijevic, N.R. (1977). Problems and implications of contrastive analysis of vocabulary and culture. Poznan Studies in Contemporary Linguistics, 7, 133-144.

Echeverría, M., \& Valencia, A. (1999). Disponibilidad léxica en estudiantes chilenos. Santiago de Chile: Universidad de Chile y Universidad de Concepción. 
Fernández Orío, S., \& Jiménez Catalán, R. M. (2015). Lexical availability of EFL learners at the end of secondary education: The effect of Language and prompt. ES Revista de Filología Inglesa, 36, 103-128.

Fuentes González, A. D. (1997). Disponibilidad léxica y fines específicos. In F. J. García Marcos (Ed.), Estudios de disponibilidad léxica (pp. 127-146). Almería, Barcelona: GRUSTA.

Gallardo del Puerto, F., \& Martínez Adrián, M. (2014). The incidence of previous foreign language contact in a lexical availability task: A study of senior learners. In R. M. Jiménez Catalán, (Ed.), Lexical availability in English and Spanish as a second language (pp. 53-68). Heidelberg: Springer.

Gallego Gallego, D. J. (2014).Léxico disponible de 82 inmigrantes estudiantes de español en la ciudad de Alcalá de Henares. Lengua y migración, 6(2), 95-123.

García Casero, M. J. (2013). El léxico disponible en estudiantes de $4^{\circ}$ de Educación Secundaria Obligatoria en Santander. PhD Dissertation. Santander: Universidad de Cantabria. $<$ http://www.tesisenred.net/bitstream/handle/10803/121587/TesisMJGC.pdf? sequence=1 $>$ [10/01/2016].

García Marcos, F. J., \& Mateo García, M. V. (1997). Resultados de las encuestas sobre disponibilidad léxica realizadas en Almería. REALE, 7, 57-68.

García Megía, A., \& García Marcos, F. J. (2005). La disponibilidad léxica en la ciudad de Almería. Almería: Universidad de Almería

Georgievska, E. (2000). Textbook vocabulary and cultural competence: A case study in EFL in the Republic of Macedonia. Durham theses, Durham University. <http://etheses.dur.ac.uk/ 4532/>. [30/01/2015].

Germany, P., \& Cartes, N. (2000). Léxico disponible en inglés como segunda lengua en instrucción formalizada. Estudios Pedagógicos, 26, 39-50.

Ghaniabadi, S., \& Alavi, N. (2012). The impact of teaching culture on reading comprehension and vocabulary knowledge in Iranian EFL learners. Unpublished masters' thesis, Hakim Sabzevari University, Sabzevar, Iran.

Gómez, L. F. (2012). Fostering Intercultural Communicative Competence through reading authentic literary texts in an advanced Colombian EFL classroom: A constructivist perspective. Profile, 14(1), 49-66.

González Fernández, J. (2013). La disponibilidad léxica de los estudiantes turcos de español como lengua extranjera. MarcoELE Revista de Didáctica ELE, 16. < http://marcoele.com/descargas/16/gonzalez-disponibilidad_lexica_turcos.pdf> [25/01/2016]

Gougenheim, G.R., Michéa, R., Rivenc, P., \& Sauvageot, A. (1954). L'élaboration du français élémentaire. Paris: Didier. 
Gougenheim, G.R., Michéa, R., Rivenc, P., \& Sauvageot, A. (1964). L'élaboration du français fondamental $1^{\text {er }}$ degré. Etude sur l'élaboration d'un vocabulaire et d'un grammaire de base. Nouvelle édition refounde et argumentée. Paris: Didier.

Grant, E, \& Payne, K. (2010). Viewpoints for Bachillerato 2 (Student's Book). Limassol: Burlington Books.

Gray, J. (2010). The Construction of English. Culture, consumerism and promotion in the ELT global coursebook. New York: Palgrave Macmillan.

Hall, J. K. (2002). Teaching and researching language and culture. Harlow: Pearson.

Han, Y-J., \& Bae, Y-S. (2005). An analysis of the cultural content of High School and College English textbooks. 영어교육, 60, 47-70.

Hayati, A. M. (2009). The Impact of Cultural Knowledge on Listening Comprehension of EFL Learners. English Language Teaching 2(3), 144-152.

Hernández Muñoz, N. (2010). Social aspects of oral and lexical written production in Spanish. Sky Journal of Linguistics, 23, 101-123.

Hu, M.; \& Nation, P. (2000). Vocabulary density and reading comprehension. Reading in a Foreign Language, 13, 403-430.

Jiménez Catalán, R. M. (Ed.) (2015). Lexical availability in English and Spanish as a second language. Heidelberg: Springer.

Jiménez Catalán, R. M., \& Fitzpatrick, T. (2014). Frequency profiles of EFL learners' lexical availability In R. M. Jiménez Catalán (Ed.), Lexical availability in English and Spanish as a second language (pp. 83-100). Heidelberg: Springer.

Jimenez Catalán, R. M., \& Mancebo Francisco, R. (2008). Vocabulary input in EFL textbooks. RESLA, 21, 147-165.

Jiménez Catalán, R. M., \& Ojeda Alba, J. (2009). Girls' and boys' lexical availability in EFL. ITL Journal of Applied Linguistics, 158, 57-76.

Jiménez, R. T., García, G. E., \& Pearson, P. D. (1996). The reading strategies of bilingual Latina/o students who are successful English readers: Opportunities and obstacles. Reading Research Quarterly, 31, 90-112.

Jin, L. (2012). El estudio de disponibilidad léxica de los estudiantes chinos de español como lengua extranjera. Marcoele Revista de Didáctica ELE, 14, 1-14.

Kachru, B. B. (1985). Standards, codification and sociolinguistic realism: The English language in the Outer Circle. In R. Quirk \& H. G. Widdowson (Eds.), English in the world: Teaching and learning the language and literatures. Cambridge: Cambridge University Press

Kramsch, C. (1993). Context and culture in language teaching. Oxford: Oxford University Press.

Krantz, C. (2012). Move on 2 (Student's Book). Oxford: Oxford University Press. 
Liddicoat, A., \& Scarino, A. (2013). Intercultural Language Teaching and Learning. Malaysia: WilleyBlackwell.

López Chávez, J., \& Strassburguer Frías, C. (1991). Un modelo para el cálculo de del índice de disponibilidad léxica. In H. López Morales (Ed.), La enseñanza del español como lengua materna (pp. 91-112). Río Piedras: Universidad de Puerto Rico.

López González, A. M. (2014). The effect of instruction on Polish Spanish learners' lexical availability. In R. M. Jiménez Catalán (Ed.), Lexical availability in English and Spanish as a second language (pp. 139-168). Heidelberg: Springer.

López Morales, H. (1973). Disponibilidad léxica de los escolares de San Juan. Ms.

Lund, R. 2006. Questions of culture and context in English Language textbooks: A study of textbooks for the teaching of English in Norway. PhD dissertation. Bergen: University of Bergen.

Magnúsdóttir, S. (2012). Disponibilidad léxica en alumnos de español como lengua extranjera. Estudio sobre el léxico disponible en alumnos de ELE en la secundaria en Islandia. MA Thesis. $<$ http://skemman.is/en/stream/get/1946/12744/31050/3/Sigr\%C3\%BA> [31/01/2016]

Mahmood M. A., Asghar, A. M., \& Hussain, Z. (2012). Cultural representation in ESL Textbooks in Pakistan: A Case Study of "Step Ahead 1". Journal of Education and Practice, 3(9), 35-42.

McKay, S. L. (2003). Toward and appropriate EIL pedagogy: Re-examining common ELT assumptions. International Journal of Applied Linguistics, 13(1), 1-22.

Nation, P. (2001). Learning Vocabulary in Another Language. New York: Cambridge University Press.

Rahimi, M \& Hassini, M. (2012) Attitude towards EFL textbooks as a predictor of attitude towards learning English as a foreign language. Procedia - Social and Behavioural Sciences, $31,66-72$.

Richards, J.C. (2001). The role of textbooks in a language program. RELC Guidelines, 23 (2), 1216.

Risager, K. (1991). Cultural references in European textbooks: An evaluation of recent tendencies. In D. Buttjes \& M. Byram (Eds.), Mediating languages and cultures (pp. 180-192). Clevedon: Multicultural Matters.

Rodríguez Muñoz F. J. and. Muñoz Hernández, I. O. (2011). Disponibilidad léxica sobre palabras específicas en estudiantes de Educación Secundaria de Almería. Espiral: Cuadernos del Profesorado, Vol. 4 (8), 22-31.

Rubio Santana, J. M. (2013). Advanced Contrast for Bachillerato 2. (Teacher's Book). Limassol: Burlington Books.

Rubio Santana, J. M., \& Grant, E. (2007). Top Marks for Bachillerato 2 (Teacher's Book). Limassol: Burlington Books. 
Rubio Santana, J. M., \& Grant, E. (2010). Viewpoints for Bachillerato 2 (Teacher's Book). Limassol: Burlington Books.

Sudartini, S. (2012). Inserting local culture in English language teaching to promote character education. Jurnal Pendidikan Karakter, 45-54.

Samper Hernández, M., \& Jiménez Catalán, R. M. (2014). Researching lexical availability in a Second Language. In R. M. Jiménez Catalán (Ed.), Lexical availability in English and Spanish as a second language (pp. 189-205). Heidelberg: Springer.

Samper Padilla, J. A., \& Hernández Cabrera, C. E. (1997). Estudio de la disponibilidad léxica en Gran Canaria. In M. Almeida, M. \& J. Dorta (Eds.), Contribuciones al estudio de la lingüística hispánica. Homenaje a Ramón Trujillo Carreño (pp. 229-239). La Laguna: Universidad de la Laguna.

Sercu, L. (2000). Acquiring intercultural communicative competence from textbooks: the case of Flemish adolescent pupils learning German. Studia paedagogica, 28. Leuven: Leuven, University Press 2000.

Serrano Zapata, M. (2004). Aspectos sociolingüisticos del léxico disponible castellano de los preuniversitarios leridanos. Pragmalingüística, 12, 147-168.

Shin, J., Eslami, Z. R., \& Chen, W-C. (2011). Presentation of local and international culture in current international English-language teaching textbooks. Language, Culture and Curriculum, 24 (3), 253-268. DOI: 10.1080/07908318.2011.614694.

Šifrar Kalan, M. (2014a). Disponibilidad léxica en diferentes niveles de Español/Lengua Extranjera. Studia Romanica Posnaniensia, Vol. 41 (1), 63-85.

Šifrar Kalan, M. (2014b). Slovene students' lexical availability in English and Spanish. In R. M. Jiménez Catalán (Ed.), Lexical availability in English and Spanish as a second language (pp. 125-138). Heidelberg: Springer.

Silvia, A. (2014). Cultural content in English textbooks used at Madrasah Tsanawiyah Negeri in Dki Jakarta. MA Thesis. English Department. Yakarta: UIN.

Tajeddina, Z., \& Teimournezhadb, S. (2015). Exploring the hidden agenda in the representation of culture in international and localised ELT textbooks. The Language Learning Journal, 43 (2), 180-193. DOI:10.1080/09571736.2013.869942

Tas, S. (2010). A critical evaluation of New English File series in terms of culture teaching. ODÜ Sosyal Bilimler Enstitüsü, 1(2), 168-177. <http://sobiad.odu.edu.tr/files/cilt1/cil1sayi2_pdf/ tas_seda.pdf> [26/11/2014].

Tomlinson, B. (2002). Materials Development. In R. Carter \& D. Nunan (Eds.), The Cambridge guide to teaching English to speakers of other languages (pp. 66-71). Cambridge: Cambridge University Press.

Ulrich, N. (2004). Towards a methodology for analysing the cultural content of modern foreign Language textbooks. Internationale Schulbuchforschung. 26 (2), 165-179.

Revista de Lenguas para Fines Específicos 22.2 
Verhoeven, L. T. (1990). Acquisition of reading in a second language. Reading Research Quarterly, 25, 90-114.

Wierzbicka, A. (1997). Understanding cultures through their key words. Oxford: Oxford University Press.

Williams, R. (1976). Keywords: A vocabulary of culture and society. New York: Oxford University Press.

Williams, A., \& Baines, M. (2013). Advanced Contrast for Bachillerato 2. (Student's Book). Limassol: Burlington Books.

Woods, M., \& Grant, E. (2007). Top Marks for Bachillerato 2 (Student's Book). Limassol: Burlington Books.

Wright, M. (1999). Influences on learner attitudes towards foreign language and culture. Educactional Research, 41, 197-208.

Xu, Z. (2013). Globalization, culture and ELT materials: A focus on China. Multilingual Education, $3(6)<$ http://www.multilingual-education.com/content/3/1/6> [20/01/2016]. 